\title{
Historical Development of Health Research Ethics in Nepal
}

\author{
Pratik Khanal, ${ }^{1}$ Sajana Maharjan, ${ }^{2}$ Namita Ghimire, ${ }^{3}$ Khem Bahadur Karki ${ }^{3}$ \\ ${ }^{1}$ Global Health Unit, Institute of Medicine, Kathmandu, Nepal, ${ }^{2}$ One Heart World-wide, Kathmandu, Nepal, \\ ${ }^{3}$ Nepal Health Research Council, Ramshah Path, Kathmandu, Nepal.
}

\begin{abstract}
Health research in Nepal initiated with a survey in malaria in 1952. The first regulatory body for health research was Nepal Medical Research Committee formed under Ministry of Health. Ethical Review Body is the first ethical review structure. Nepal Health Research Council is now an independent body to regulate health research in Nepal. Development of research ethics in Nepal is clearly evident with the development of ethical guidelines; functioning of Ethical Review Board; expansion of institutional review committees and initiation of online submission system. However, monitoring compliance with research ethics could be a challenge for the Nepal Health Research Council.

Keywords: Health research; Nepal; research ethics.
\end{abstract}

\section{INTRODUCTION}

Maintaining research ethics is an important component of health research, the main purpose being the protection of research participants. Nepal Health Research Council (NHRC), an apex government body of health research in Nepal, is responsible to promote responsible conduct of research by setting ethical standards and norms. ${ }^{1}$ Besides regulating research, NHRC is involved in generating evidences, publication of research reports and journals, and research capacity building of the health professionals. This paper documents the development of health research ethics in Nepal under three timelines: Early developments (1952-1991), Developments after establishment of NHRC (1992-2002) and Developments after the formation of Ethical Review Board (ERB) under NHRC (2002-2017).

\section{EARLY DEVELOPMENTS OF RESEARCH ETHICS IN NEPAL (1952-1991)}

The origin of health research in Nepal dates back to 1952 when United States Operations Mission conducted a survey on malaria. ${ }^{2}$ History of research publication in Nepal started with the initiation of Journal of Nepal Medical Association in 1963 and the Journal of Institute of Medicine in 1979. ${ }^{3,4}$ Nepal Medical Research Committee (NMRC), the first regulatory body of health research, was established on April 15, 1982 under Ministry of Health. ${ }^{5}$ The committee was entrusted with the responsibility to coordinate with stakeholders working in health research, generate and exchange evidences, and approve health research proposals. The NMRC on June 27, 1982 established a three member Ethical review body, the first ethical review structure in Nepal, comprising of Dr. Mrigendra Raj Pandey, Dr. Hemang Dixit and Dr. Santosh Man Shrestha. ${ }^{6}$ The first research approved by NMRC was a study on hypertension by World Health Organization (WHO) in the same year. ${ }^{6}$ The important decisions made by NMRC were the requirement of Nepalese investigator in the foreign led research project (September 1983); establishment of Institution Strengthening Subcommittee to review the benefits of research to health system (December 1987) and formation of Monitoring and Evaluation Sub-committee to monitor the progress of research projects (January 1989). ${ }^{6}$

\section{DEVELOPMENTS AFTER ESTABLISHMENT OF NHRC (1991-2002)}

The NMRC was developed into NHRC through the NHRC Act no 129 of the year 1991 of Nepal Government. ${ }^{1}$ Ethical sub-committee led by Dr. Dibya Shree Malla was formed thereafter. Considering the wider impact of research ethics in the health of people, NHRC on July 29, 1992 in consultation with then Chief justice Bishwanath Upadhyaya appointed him as the chairperson of the Ethical sub-committee. After Mr. Upadhyaya, then Judge of the Supreme Court, Mr. Nayan Bahadur Khatri and health expert Dr. Basanta Lal Shrestha led 
the sub-committee subsequently. ${ }^{6}$ The executive body meeting of NHRC held on June 29, 1995 decided to allow transportation of medical herbs and human biosamples outside Nepal for research only after approval from NHRC. ${ }^{6}$ After Dr. Shrestha, Prof. Dr. Ramesh Kanta Adhikari led the Ethical sub-committee. The efforts for developing national ethical guidelines started from January 2000 which led to the development of national ethical guidelines in July, 2001. ${ }^{5}$

\section{DEVELOPMENTS AFTER THE FORMATION OF ERB IN NHRC (2002-till March 2017)}

As per the provision in the National Ethical Guidelines 2001, ERB was formed whose first meeting was held on March 13, 2002. Prof. Adhikari led the ERB as a Coordinator from March 2002 to October 2014. Ethical guidelines related to Institutional Review Committees (IRCs), clinical trials, use of animals in health research and standard operating procedures of ERB were developed during his leadership. Prof. Dr. Jeevan Bahadur Sherchand replaced Prof. Adhikari as the coordinator of ERB in 2014 and during his leadership, revision of IRC guidelines and draft of biomedical guidelines has been prepared and online submission system of research proposal has been initiated. The ERB has also delegated its authority to 29 IRCs based at different academic institutions and hospitals. The ERB is responsible to monitor IRCs and research projects in addition to approval of research proposals. A brief outline of the development of research ethics is presented in Table 1.

\begin{tabular}{|c|c|}
\hline Year & Developments \\
\hline 1982 & $\begin{array}{l}\text { Establishment of NMRC under Ministry of } \\
\text { Health }\end{array}$ \\
\hline 1982 & $\begin{array}{l}\text { Formation of Ethical Review Body under } \\
\text { NMRC. }\end{array}$ \\
\hline 1983 & $\begin{array}{l}\text { Provision to have a Nepalese investigator in } \\
\text { foreign research team }\end{array}$ \\
\hline 1991 & $\begin{array}{l}\text { Establishment of NHRC through NHRC Act } \\
1991\end{array}$ \\
\hline 1992 & Ethical sub-committee formed under NHRC \\
\hline 1995 & $\begin{array}{l}\text { Permission of NHRC needed for transportation } \\
\text { of medical herbs and human bio-samples to } \\
\text { foreign country for research. }\end{array}$ \\
\hline 2001 & $\begin{array}{l}\text { National Ethical Guidelines was developed } \\
\text { and ERB established. }\end{array}$ \\
\hline 2005 & $\begin{array}{l}\text { Guideline for IRCs, Ethical Guidelines for use } \\
\text { of animals in health research and National } \\
\text { guideline on clinical trials were developed }\end{array}$ \\
\hline
\end{tabular}

2011 National Ethical Guidelines for Health Research in Nepal and Standard Operating Procedures was developed.

2014 Ethical Review and Monitoring and Evaluation Section formed.

2016 Revised Guidelines for IRCs published.

2016 Restriction on transportation of whole biosamples outside Nepal

2017 Initiation of online submission system of research proposal

\section{CONCLUSIONS AND WAY FORWARD}

Over the time, developments in research ethics in Nepal are clearly evident with the development of ethical guidelines, functioning of ERB and IRCs, increment in the proposal submission for ethical review and training of health professionals in research ethics. However, not all researches are conducted with ethical approval in Nepal. 2, 7 Students and faculties not affiliated with IRCs and health research conducted by academia related to social science and science and technology disciplines usually do not go through ethical review. Researchers often are confused with acceptance from the study site as ethical approval. Thus, researchers and research organizations need to be made aware of the need of ethical approval. Monitoring of the compliance of research ethics should also be strengthened which could be difficult for NHRC in the current context as it does not have an expansive network and the IRCs are limited to monitor only inhouse researches. The structure of NHRC thus needs to be carefully discussed in the country's federal context. NHRC can be a major stakeholder in health system if it strengthen its regulatory functions, prioritize research areas and conduct functions related to knowledge management. We expect a stronger presence of NHRC in maintaining research ethics in the future.

\section{ACKNOWLEDGEMENTS}

The authors like to acknowledge Mr Nirbhay Kumar Sharma, the Administration Chief of NHRC, Mr Sudip Poudel, Senior Publication Assistant at NHRC and all the attendees of celebration program of $200^{\text {th }}$ ERB meeting held in NHRC for their support in preparation of the manuscript.

\section{REFERENCES}

1. GoN. Nepal Health Research Council Act. Government of Nepal: Law Commission. 1991.p. 5.

2. Sharma JR, Khatri R, Harper I. Understanding Health Research Ethics in Nepal. Developing world bioethics. 2016. 


\section{[Full Text]}

3. SinghY. Building a health research culture in Nepal: An initiative from the Institute of Medicine. Journal of Institute of Medicine. 2017; 40(2).[Full Text]

4. Shrestha RM. Scientific Medical Publication in Nepal. Orthodontic Journal of Nepal. 2014; 3(2): 5-6.[Full Text]

5. NHRC. NHRC Milestone. 2017. http://nhrc.gov.np/ about/nhrc-milestone/ (accessed 10/11/2017).
6. NHRC. Meeting minutes of Executive Body of NHRC and Ethical Review Board. Kathmandu: NHRC. 1982-2016.

7. Van Teijlingen E, Simkhada P. Failure to apply for ethical approval for health studies in low-income countries. Nepal journal of epidemiology. 2015; 5(3): 511.[Full Text] 